DOI: 10.34015/2523-4552.2021.2.04

УДК 343.8
Колб О. Г., доктор юридичних наук, професор, заслужений юрист Украӥни, професор кафедри кримінології та кримінально-виконавчого права Національного юридичного університету імені Ярослава Мудрого ORCID: 0000-0003-1792-4739
Колб Р. О., здобувачка кафедри кримінального права і процесу Волинського національного університету імені Лесі Українки ORCID: 0000-0003-0187-3391

\title{
НАЦІОНАЛЬНИЙ БАНК УКРАЇНИ ЯК СУБ'ЄКТ ЗАПОБІГАННЯ КРИМІНАЛЬНИМ ПРАВОПОРУШЕННЯМ
}

У даній статті здійснено аналіз змісту законодавчих актів, які регулюють діяльність Національного банку України та визначають його зміст у контексті запобігання кримінальним правопорушенням у зазначеній галузі суспільних відносин, а також запропоновано науково обгрунтовані заходи, спрямовані на усунення існуючих у зв'язку з цим проблем.

Ключові слова: Національний банк України; кримінальне правопорушення; банківська діяльність; запобігання; суб'єкт запобіжної діяльності; клієнт банку; правові підстави.

В данной статье осуществлен анализ содержания законодательных актов, регулирующих деятельность Национального банка Украины и определяют его содержания в контексте предупреждения уголовным правонарушениям в указанной отрасли общественных отношений, а также предложены научно обоснованные мероприятия, направленные на ликвидацию существующих в связи с этим проблем.

Ключевые слова: Национальный банк Украины; уголовное правонарушение; банковская деятельность; предупреждения; субъект предупредительной деятельности; клиент банка; правовые основания.

Постановка проблеми. Як показали результати вивчення нормативно-правових актів, законодавство України про банківську діяльність становить Конституція України, міжнародні договори, згода на обов'язковість яких надана Верховною Радою України та інші закони. Крім цього, відповідно до вимог Закону України «Про Національний банк України», письмові рішення Національного банку, видані в на- 
лежному порядку та в межах його повноважень і за змістом не суперечать чинному законодавству та не пов'язані 3 порушенням конституційних прав та свобод людини і громадянина, підлягають виконанню іншими банківськими установами та їх філіями, включаючи й за кордоном. При цьому, у разі суперечності норм цього Закону нормам інших законодавчих актів, включаючи відповідні Кодекси України, норми зазначеного Закону мають перевагу.

Проте, варто визнати, що якщо застосовувати при цьому системний підхід, то відповідної видозміни у зв'язку з цим потребують всі нормативно-правові акти, які стосуються банківської та запобіжної діяльності у зазначеній галузі суспільних відносин. Зокрема, знову ж таки, у цьому сенсі звертають на себе увагу окремі положення Закону України «Про Національний банк України». Так, у даному Законі відсутня така норма, яка визначала б завдання вказаної установи, що $\epsilon$ необхідною та обов'язковою для будь-якого державного органу.

При цьому, якщо врахувати той факт, що завдання банківських установ не закріплені і в базовому Законі України «Про банки i банківську діяльність», то ця проблема набуває не тільки і не стільки теоретичної значущості, скільки має прикладний характер для банківської системи, що й обумовило вибір предмета дослідження у даній науковій статті.

Постановка завдання. Враховуючи зазначене вище, метою цієї наукової статті $€$ обгрунтування за результатами проведеного аналізу наукової літератури та практики ролі та місця Національного банку України у системі суб'єктів за- побігання кримінальним правопорушенням, а головним завданням розробка на вказаній основі науково обгрунтованих заходів, спрямованих на підвищення рівня запобіжної діяльності даного суб'єкта профілактики та результативності взаємодії 3 цих питань 3 правоохоронними органами.

Аналіз останніх досліджень і публікацій. Вивчення наукової літератури показало про те, що ця тематика не $\epsilon$ новою, ï постійно досліджують, насамперед фахівці адміністративного та фінансового права, а також інших галузей юриспруденції (господарського, цивільного, корпоративного права тощо), утім кримінологи - недостатньою мірою. Зокрема, досить активно у цьому напрямі працюють такі із них, як: Л. І. Аркуша, О. М. Бандурка, А. М. Бойко, В. І. Борисов, М. О. Буровиш, Т. С. Васильєва, В. В. Василевич, К. П. Глоба, В. В. Голіна, Б. М. Головкін, О. М. Джужа, . О. Допілка, В. М. Дрьомін, О. О. Дудоров, В. П. Ємельянов, А.Г. Зінченко, Д. В. Каменський, О.Г.Колб, І. М. Копотун, О. О. Крестянникова, О. М. Литвинов, О. М. Литвак, І. Б. Медицький, Ю. О. Новосад, А. В. Савченко, Л. М. Скора, А. В. Смирнова, Є. П. Стрельцов, В. О. Туляков, П. Л. Фріс, В. В. Шаблистий, В. І. Шакун, О. О. Юхно та ін.

Водночас, на сьогодні комплексних наукових розробок щодо діяльності банківських установ як суб'єктів запобігання кримінальним правопорушенням у відповідній галузі не проводили, що актуалізує необхідність дослідження цієї проблематики, а також визначає iï наукову новизну, теоретичне та практичне значення. 3 огляду на це та з урахуванням сучасного (2014- 
2020 рр.) стану запобіжної діяльності в банківській системі України, обрано об’єкт і предмет цієї роботи, а також визначено її мету й завдання.

Виклад основного матеріалу. У контексті вирішення завдань цієї наукової розробки, важливе значення для удосконалення змісту запобіжної діяльності банківських установ як суб'єктів соціального контролю та профілактики, без сумніву, відіграють всі, без винятку, закони, які регулюють вказану галузь суспільних відносин. Проте, варто при цьому зазначити, що без видозміни змісту двох («Про банки та банківську діяльність» та «Про Національний банк України») законів, об'єктивно неможливо системно вирішити проблему щодо наділення банків запобіжними функціями і завданнями, навіть при тому, що у нормативно-правових актах, що стосуються банківської діяльності, $\epsilon$ відповідні норми (статті, глави, розділи тощо), які мають у собі профілактичну складову (як от: запобігання та протидія легалізації (відмиванню) доходів, одержаних кримінальним шляхом; право на застосування заходів впливу до порушників банківського законодавства; позбавлення ліцензій на зайняття банківською діяльністю тощо).

У той самий час, як показали результати даного дослідження, чимало потенційних можливостей 3 означених питань міститься й $\mathrm{y}$ рішеннях Національного банку України. Зокрема, як це витікає із змісту ст. 56 Закону України «Про Національний банк України», зазначена установа (як особливий центральний орган державного управління (ст. 2 цього Закону)), видає нормативно-правові акти 3 питань, що віднесені до його повноважень, які $\epsilon$ обов'язковими для органів держаної влади і органів місцевого самоврядування, юридичних та фізичних осіб. При цьому слід звернути увагу на декілька особливостей, що впливають на зміст рішень Національного банку України:

1. Ці рішення видаються у виді розпорядних актів 3 питань організаційно-розпорядного характеру або індивідуальної дії, які не $\epsilon$ нормативно-правовими актами (ч. 3 ст. 56 зазначеного Закону), що суперечить як в цілому логіці цього Закону, так і ст. 4 Закону України «Про банки та банківську діяльність», згідно до вимог якої Національний банк України здійснює нормативноправове забезпечення операцій, які вчиняються спеціалізованими банками.

Враховуючи зазначене, як видається, слід виключити 3 ч. 3 ст. 56 Закону України «Про Національний банк України» слово «не», надавши таким чином розпорядним актам цієї банківської установи нормативноправового характеру.

2. Ці рішення видаються у формі:

а) постанов Правління Національного банку України;

б) інструкцій, положень і правил, що затверджуються постановами Правління НБУ.

При цьому, зазначені рішення не можуть суперечити законам України та іншим законодавчим актам України, і не мають зворотної сили, крім випадків, коли вони згідно із законами пом'якшують або скасовують відповідальність (ч. 4 ст. 56 зазначеного Закону). Поряд з цим варто звернути увагу на той факт, що 
у даній нормі немає жадного слова про Конституцію України, згідно ст. 8 якої її положення мають найвищу юридичну силу, а також ст. 19 Закону України «Про міжнародні договори», у якій зазначено, що останні, згоду на обов'язковість яких надана Верховною Радою України, мають перевагу у правозастосуванні при умові, якщо регулюють певну сферу суспільної діяльності поряд 3 відповідними нормами вітчизняного законодавства.

Виходячи з цього та враховуючи, що серед правових підстав діяльності Національного банку України (ст. 2 Закону України «Про Національний банк України») відсутні зазначені вище правові джерела (міжнародні договори), логічно було б друге речення ч. 4 ст. 56 даного Закону доповнити словосполученням «Конституції України та міжнародним договорам, згода на обов'язковість яких надана Верховною Радою України», та викласти ії̈ у новій редакції:

«Нормативно-правові акти Національного банку України не можуть суперечити Конституції України, та міжнародним договорам, згода на обов'язковість яких надана Верховною Радою України, Законом України та іншим законодавчим актам України і не мають зворотної сили, крім випадків, коли вони згідно із законом пом'якшують або скасовують відповідальність».

Знову ж таки, даючи розширене тлумачення словосполучення «законодавчі акти України», у даному випадку варто виходити із змісту рішення Конституційного Суду України від 09 липня 1998 року № 12-пр/98, відповідно до якого, крім Конституції України, міжнарод- них договорів, згода на обов'язковість яких надана Верховною Радою України, до таких актів відносяться: закони України, постанови Верховної Ради України, постанови (декрети) Кабінету Міністрів України [1].

3. Ці рішення приймаються 3 урахуванням вимог Закону України «Про засади державної регуляторної політики у сфері господарської діяльності», тобто фактично також носять нормативно-правовий характер.

4. Ці рішення публікуються у тих офіційних відомостях, у яких оприлюднюються прийняті нові закони та інші нормативно-правові акти, що теж свідчать про належність цих рішень до переліку останніх.

5. Ці рішення можуть бути оскаржені відповідно до законодавства України.

Зокрема, предметом розгляду в судах адміністративної юрисдикції, згідно Кодексу адміністративного судочинства України, $\epsilon$ й рішення Національного банку України (ст. 4).

6. Ці рішення (нормативноправові акти чи індивідуальні акти), дії або бездіяльність Національного банку чи його посадових та службових осіб можуть бути оскаржені до суду виключно з метою їх законності (ч. 1 ст. 74 Закону України «Про Національний банк України»).

Знову ж таки, співставивши це положення не тільки із змістом ст. 56 зазначеного Закону, але й інших законів, зокрема Кодексу адміністративного судочинства України, а, головне, - із ст. 124 Конституції України, відповідно до положень якої юрисдикція судів поширюється на будь-який юридичний спір, то, навіть не чекаючи 3 цього приводу 
офіційного тлумачення Закону України «Про Національний банк України», можна зробити очевидний висновок про те, що вказана норма суперечить Основному закону, а тому має бути вилучена із вказаної статті Закону України «Про Національний банк України».

Крім цього, закріплене в ст. 74 зазначеного Закону положення не відповідає й змісту ст. 55 Конституції України, у якій зазначено, що кожному гарантується право на оскарження в суді рішення, дій чи бездіяльності органів державної влади, органів місцевого самоврядування, посадових і службових осіб. При цьому, ні в ст. 55, ні в ст. 124 Основного закону України жодних обмежень щодо предмету судового розгляду не встановлено.

Такий підхід, крім цього, підтверджується змістом ч. 2 ст. 41 КК України, відповідно до якої наказ або розпорядження (у даному випадку - рішення Національного банку України) $\epsilon$ законними, якщо вони видані відповідною особою, в належному порядку та в межах її повноважень і за змістом не суперечать чинному законодавству та не пов'язані з порушенням конституційних прав та свобод людини і громадянина.

Отже, видозміна ч. 1 ст. 74 Закону України «Про Національний банк України» $є$ необхідною та нормативно вмотивованою. Важливість вирішення цього питання обумовлюється ще й тим, що у сенсі здійснення банківськими установами функцій щодо запобігання кримінальним правопорушенням у галузі банківської діяльності дотримання принципу законності $\epsilon$ обов'язковим системним елементом їх функціонування.
Саме 3 цих міркувань, варто надати Національному банку України таку функцію, як запобігання вчиненню у банківській сфері кримінальних правопорушень, а також внести у зв'язку 3 цим науко-во обгрунтовані зміни у базовий Закон України «Про банки та банківську діяльність». При цьому необхідно зазначити, що у даній науковій статті авторська позиція із вказаної проблематики базується на сучасних наукових розробках, а саме - на результатах монографічного дослідження 0 . В. Уткіної «Система управління банківськими ризиками легалізації доходів, отриманих злочинним шляхом» (2019 рік) [2]; С. С. Мельника «Виявлення та запобігання фінансовому шахрайству у забезпеченні фінансової безпеки комерційних банків» (2019 рік) [3]; А. А. Сисоєвої «Аналіз ринку великих даних у банківській сфері» (2017 рік) [4] та інших учених [5].

При цьому, слід звернути увагу на декілька особливостей, що впливають на зміст рішень Національного банку України:

1. Ці рішення видаються у виді розпорядних актів 3 питань організаційно-розпорядного характеру або індивідуальної дії, які не є нормативно-правовими актами (ч. 3 ст. 56 зазначеного Закону), що суперечить як в цілому логіці цього Закону, так і ст. 4 Закону України «Про банки та банківську діяльність», згідно до вимог якої Національний банк України здійснює нормативно-правове забезпечення операцій, які вчиняються спеціалізованими банками.

Враховуючи зазначене, слід виключити 3 ч. 3 ст. 56 Закону України «Про Національний банк України» слово «не», надавши таким 
чином розпорядним актам цієї банківської установи нормативноправового характеру.

2. Ці рішення видаються у формі:

а) постанов Правління Національного банку України;

б) інструкцій, положень і правил, що затверджуються постановами Правління НБУ.

При цьому, зазначені рішення не можуть суперечити законам України та іншим законодавчим актам України, і не мають зворотної сили, крім випадків, коли вони згідно із законами пом'якшують або скасовують відповідальність (ч. 4 ст. 56 зазначеного Закону).

Поряд 3 цим варто звернути увагу на той факт, що у даній нормі немає жадного слова про Конституцію України, згідно ст. 8 якої її положення мають найвищу юридичну силу, а також ст. 19 Закону України «Про міжнародні договори», у якій зазначено, що останні, згоду на обов'язковість яких надана Верховною Радою України, мають перевагу у правозастосуванні при умові, якщо регулюють певну сферу суспільної діяльності поряд з відповідними нормами вітчизняного законодавства.

Виходячи з цього та враховуючи, що серед правових підстав діяльності Національного банку України (ст. 2 Закону України «Про Національний банк України») відсутні зазначені вище правові джерела (міжнародні договори), логічно було б друге речення ч. 4 ст. 56 даного Закону доповнити словосполученням «Конституції України та міжнародним договорам, згода на обов'язковість яких надана Верховною Радою України», та викласти її у новій редакції:
«Нормативно-правові акти Національного банку України не можуть суперечити Конституції України, та міжнародним договорам, згода на обов'язковість яких надана Верховною Радою України, Законом України та іншим законодавчим актам України і не мають зворотної сили, крім випадків, коли вони згідно із законом пом'якшують або скасовують відповідальність».

Знову ж таки, даючи розширене тлумачення словосполучення «законодавчі акти України», у даному випадку варто виходити із змісту рішення Конституційного Суду України від 09 липня 1998 року № 12-пр/98, відповідно до якого, крім Конституції України, міжнародних договорів, згода на обов'язковість яких надана Верховною Радою України, до таких актів відносяться: закони України, постанови Верховної Ради України, постанови (декрети) Кабінету Міністрів України [1].

3. Ці рішення приймаються 3 урахуванням вимог Закону України «Про засади державної регуляторної політики у сфері господарської діяльності», тобто фактично також носять нормативно-правовий характер.

4. Ці рішення публікуються у тих офіційних відомостях, у яких оприлюднюються прийняті нові закони та інші нормативно-правові акти, що теж свідчать про належність цих рішень до переліку останніх.

5. Ці рішення можуть бути оскаржені відповідно до законодавства України.

Зокрема, предметом розгляду в судах адміністративної юрисдикції, згідно Кодексу адміністративного судочинства України, $€$ й рішення Національного банку України (ст. 4). 
6. Ці рішення (нормативноправові акти чи індивідуальні акти), дії або бездіяльність Національного банку чи його посадових та службових осіб можуть бути оскаржені до суду виключно з метою їх законності (ч. 1 ст. 74 Закону України «Про Національний банк України»).

Поряд 3 цим, заслуговує у зв'язку з цим на увагу узагальнений висновок, що стосується змісту запобіжної діяльності, включаючи й банківську сферу України, який у свій час зробили вчені, а саме: закон має бути оптимально узгоджений із чинним законодавством та не повинен суперечити Конституції України та міжнародним зобов'язанням нашої держави [6, с. 345], що є досить актуальним 3 огляду на існуючі у банківській сфері проблеми запобіжного характеру, правові прогалини та колізії [7, с. 1-2].

Висновки. Отже, сьогоднішне конституційне, законодавче та інше нормативно-правове забезпечення діяльності банків як суб'єктів запобігання кримінальним правопорушенням в Україні не в повній мірі відповідає тим реаліям, які склались у зазначеній сфері суспільних відносин, що виступає однією 3 детермінант, яка спричинює та обумовлює вчинення вказаних вище суспільно небезпечних діянь, а також негативно впливає не тільки на ефективність банківської, але інших видів діяльності цих установ, включаючи у тому числі й діяльність профілактичного.

\section{Список використаних джерел}

1. Рішення Конституційного Суду України «У справі за конституційним зверненням Київської міської ради, професійних спілок щодо офіційного тлумачення частини третьої статті 21 Кодексу законів про працю України (справа про офіційне тлумачення терміну «законодавство») від 09 липня 1998 року № 12-пр/98. Обіційний вісник України. 1998. № 32. Ст. 1209.

2. Уткіна О. В. Система управління банківськими ризиками легалізації доходів, отриманих злочинним шляхом: Автореф. дис. ... канд. економ. наук: 08.00.08. Київ: Державний вищий навчальний заклад «Університет банківської справи», 2019. 22 с.

3. Мельник С. С. Виявлення та запобігання фінансовому шахрайству у забезпеченні фінансової безпеки комерційних банків: Автореф. дис. ... канд. економ. наук: 08.00.08. Київ: Державний вищий навчальний заклад «Університет банківської справи», 2019. 22 с.

4. Сысоева А., Эюбов 3., Фошкин А. Анализ рынка больших данных в банковской сфере. Финансовая жизнь. 2017. № 1. С. 32-35.

5. Герасимов О. В. Протидія злочинності у банківській сфері: Автореф. дис. ... канд. економ. наук: 12.00.08. Харків: Харків. нац. ун-т імені В. Н. Каразіна, 2019. 18 с.

6. Кримінологія: навч. посібник / О.М.Джужа, В. В. Василевич, О. Г. Колб та ін.; за заг. ред. д-ра юрид. наук, проф. О. М. Джужи. Київ: Атіка, 2009. 312с.

7. Колб Р. О. Банківська установа як суб'єкт запобігання злочинам: автореф. дис. ... канд. юрид. наук: 12.00.08. Запоріжжя: КПУ, 2021. 20 с.

\section{References}

Utkina, O. V. (2019). Systema upravlinnia bankivskymy ryzykamy lehalizatsii dokhodiv, otrymanykh zlochynnym shliakhom. (Avtoref. dys. ... kand. ekonom. nauk). Kyiv: Derzhavnyi vyshchyi navchalnyi zaklad «Universytet bankivskoi spravy». 
Melnyk, S. S. (2019). Vyiavlennia ta zapobihannia finansovomu shakhraistvu u zabezpechenni finansovoi bezpeky komertsiinykh bankiv (Avtoref. dys. ... kand. ekonom. nauk). Kyiv: Derzhavnyi vyshchyi navchalnyi zaklad «Universytet bankivskoi spravy».

Sysoeva, A., Eiubov, Z., Foshkyn, A. (2017). Analyz ronka bolshykh dannykh v bankovskoi sfere. Fynansovaia zhyzn, 1, 32-35.

Herasymov, O. V. (2019). Protydiia zlochynnosti u bankivskii sferi (Avtoref. dys. ... kand. ekonom. nauk). Kharkiv: Kharkiv. nats. un-t imeni V. N. Karazina.

Kryminolohiia: navch. posibnyk / O. M. Dzhuzha, V. V. Vasylevych, O. H. Kolb ta in.; za zah. red. d-ra yuryd. nauk, prof. O. M. Dzhuzhy. Kyiv: Atika, 2009. 312s.

Kolb, R. O. (2021). Bankivska ustanova yak sub'iekt zapobihannia zlochynam: (Avtoref. dys. ...kand.yuryd.nauk). Zaporizhzhia: KPU.

Kolb O. H., Kolb R. O. Vplyv kryminalnykh pravoporushen, shcho vchyniaiutsia v bankivskii sferi, na ekonomiku Ukrainy. Zakhyst ekonomiky vid vplyvu orhanizovanoi zlochynnosti: zbirnyk tez panelnoi dyskusii V Kharkivskoho mizhnarodnoho yurydychnoho forumu. Kharkiv: Yurait, 2021. S. 130-134.

o. Kolb, Professor of Criminology and Criminal Enforcement Law Yaroslav the Wise National University of Law Honored Lawyer of Ukraine

ORCID: 0000-0003-1792-4739

$\boldsymbol{R}$. Kolb, Candidate of the Department of Criminal Law and Procedure Lesya Ukrainka Volyn National University

ORCID: 0000-0003-0187-3391

\section{The National Bank of Ukraine as a subject of prevention of criminal offenses}

This article analyzes the content of legislative acts regulating the activities of the National Bank of Ukraine and determines its content in the context of preventing criminal offenses in this branch of public relations, and also proposes scientifically based measures aimed at eliminating the problems existing in this regard.

According to the results of the study of normative legal acts, the legislation of Ukraine on banking is the Constitution of Ukraine, international treaties, the binding nature of which has been approved by the Verkhovna Rada of Ukraine and other laws. In addition, in accordance with the requirements of the Law of Ukraine "On the National Bank of Ukraine", written decisions of the National Bank, duly issued and within its powers and content do not contradict current legislation and are not related to violation of constitutional rights and freedoms, are subject to execution by other banking institutions and their branches, including abroad. At the same time, in case of contradiction of the norms of this Law with the norms of other legislative acts, including the relevant Codes of Ukraine, the norms of the said Law shall prevail.

However, it should be recognized that if you apply a systematic approach, then the appropriate changes in this regard require all regulations relating to banking and security activities in this area of public relations. In particular, again, in this sense, certain provisions of the Law of Ukraine "On the National Bank of Ukraine" draw attention. Thus, there is no norm in this Law that would define the 
tasks of the specified institution, which is necessary and obligatory for any state body.

At the same time, if we take into account the fact that the tasks of banking institutions are not enshrined in the basic Law of Ukraine "On Banks and Banking", this problem acquires not only and not so much theoretical significance, but has an applied nature for the banking system, which led the choice of the subject of research in this scientific article.

Keywords: National Bank of Ukraine; criminal offense; banking; warnings; subject of preventive activity; bank client; legal basis. 